\title{
МЕНОПАУЗАЛЬНИЙ МЕТАБОЛІЧНИЙ СИНДРОМ: ПОГЛЯД ЕНДОКРИНОЛОГА
}

\author{
Чернявська I. В., Микитюк М. Р. \\ ДУ “Інститут проблем ендокринної патологї іл. В. Я. Данилевського НАМН Украӥни», \\ м. Харків, Україна; \\ Харківська медична акаделія післядипломної освіти МОЗ України, м. Харків, Україна \\ myroslavamk@ukr.net
}

\begin{abstract}
Менопауза - природня частина життевого циклу жінки, якій притаманні зниження рівня естрогенів і підвищення рівня фолікулостимулюючого гормону (ФСГ) в крові, підвищений ризик метаболічного синдрому (МC), атеросклерозу і серцево-судинних захворювань (СС3) $[1,2]$. Розповсюдженість МС в загальній популяції 20-30 \% [3], і зростає до 31-69 \% після менопаузи. Доведено, що менопауза пов'язана 3 підвищеним ризиком МС незалежно від віку жінки [3]. Широка розповсюдженість факторів ризику СC3 серед жінок в постменопаузі - провідна проблема профрілактичної медицини. Незважаючи на численні дослідження по первинній профрілактиці CC3 у жінок в постменопаузі, залишається ще низка невирішених питань. Недооцінка вікових особливостей функціонування репродуктивної системи може приводити як до гіпердіагностики і невиправданих лі-
\end{abstract}

кувальних втручань, так і до несвоєчасної діагностики латентної гінекологічної патології [4].

Клімактерій (перименопауза) - критичний період до менопаузи, під час якого відбувається перехід від регулярних, овуляторних менструальних циклів до угасання і припинення менструацій, зміни в ендокринній, соматичній і психічних сферах [5]. Менопаузальний перехід починаеться коли менструальні цикли втрачають сталу тривалість на тлі ізольованного підвищення рівня ФСГ і закінчуеться разом з останньою менструацією. Згідно модифікованій класифікації стадій клімактерію PENN-5 менопаузальний перехід мае три етапи, два з яких припадає на перименопаузу [6]. Відсутність менструацій впродовж року у жінки старше 45 років в $90 \%$ випадків свідчить про менопаузу [7]. Зазвичай менопауза наступае у віці 49-52 років (ме-

* Роботу виконано в межах планової наукової тематики ДУ «Інститут проблем ендокринної патології ім. В. Я. Данилевського НАМН України» «Удосконалити діагностику неалкогольної жирової хвороби печінки у хворих на цукровий діабет 2 типу за урахуванням етіопатогенетичних механізмів розвитку захворювання» (державний реєстраційний № 0119U102446).

Установою, що фінансує дослідження, е НАМН України.

Автори гарантують повну відповідальність за все, що опубліковано в статті.

Автори гарантують відсутність конфлікту інтересів і власної фінансової зацікавленості при виконанні роботи та написанні статті.

Рукопис надійшов до редакції 10.05.2021. 
діана 47,5 років). Актуальною проблемою в Україні є рання і передчасна менопауза у $20 \%$ жінок у віці до 45 років і у $8 \%$ до 40 років [8], в той час як в Свропі відсоток цих жінок становить 5 і 1 \%, відповідно [9].

В менопаузальному переході маніфестують хронічні захворювання, які впливають як на якість, так і на тривалість життя жінки: гінекологічні і СC3, остеопороз і остеоартроз, надлишкова маса або ожиріння, порушення глюкозного гомеостазу (ПГГ), урогенітальні порушення, сексуальна дисдункція, зниження когнітивних фрункцій і депресія, підвищуеться ризик онкологічних захворювань.

Згідно результатів мета-аналізу Study of Women's Health Across the Nation, середня тривалість припливів становить 7,4 років, а після останньої менструації припливи зберігаються в середньому 4,5 роки, однак у 10-15 \% жінок виразні вазомоторні прояви спостерігаються впродовж багатьох років після менопаузи [10]. Вазомоторні симптоми, особливо помірні і тяжкі, настільки сильно знижують якість життя в період менопаузального переходу і постменопаузи, що, поряд із розладами сну, депресією i порушеннями статевого потягу, значуще впливають на соціальне і економічне благополуччя пацієнтки [11].

В численних дослідженнях встановлено зв'язок між рівнем естрогенів в крові i фракторами ризику МС (дисліпідемія, ПГГ і ожиріння) [12, 13]. Крім ефректів естрогенів вивчали роль підвищеного рівня ФСГ ужінок в менопаузі. Так, L. Sun і співавтори вказують на здатність ФСГ активувати рецептор ФСГ, який експресуеться на поверхні остеокластів, і безпосередньо регулює кісткову масу, що призводить до розвитку остеопорозу, тоді як естрогени здатні нівелювати цей ефект [14]. Доведено, що рівень ФСГ в крові корелюе з рівнем загального холестерину, а блокування ФСГ пригнічує його біосинтез в печінці і знижуе рівень в крові [15]. Ризик розвитку МС у жінок в пременопаузі вище, ніж в менопаузі, що обумовлено більш високим рівнем ФСГ в крові, який асоціюеться з обводом талії, рівнем тригліцеридів (ТГ), систолічного артеріального тиску і ризиком розвитку MC [16].
У пацієнток із менопаузальним МC діагностують порушення пуринового обміну [17]. Нерідко гіперурикемія розглядається як одна з складових МС [18]. Підвищенню рівня сечової кислоти можуть сприяти також надлишкова маса тіла і ожиріння, зловживання алкоголем, прийом діуретиків [19].

Цікаво, що жінки з синдромом полікістозних яечників мають більш високий ризик розвитку МС впродовж фертильного періоду, однак з менопаузою ризик його розвитку співставимий 3 ризиком у жінок без нього [20].

У жінок в постменопаузі інсулінорезистентність (IP) формуеться на тлі активації симпатичної нервової і ренін-ангіотензинової систем, прозапальних цитокинів і розвитку атерогенної дисліпідемії. В менопаузі спостерігається гіперактивність симпатичного відділу вегетативної нервової системи, яка викликає каскад патологічних змін в організмі жінки. Так, симпатикотонія стимулюе глюконеогенез і глікогеноліз в печінці, знижуе поглинання глюкози скелетними м'язами, призводячи, в свою чергу, до розвитку гіперглікемії і гіперінсулінемії [18]. Гіперінсулінемія ранній маркер IP і ізольованний фрактор ризику ішемічної хвороби серця (IXC) [21]. ПГГ обумовлені зниженням базальної секреції інсуліну і розвитком IP на тлі гіпоестрогенемії. Протягом фертильного періоду середня концентрація загальних естрогенів становить 100-250 пг/мл, в постменопаузі - до 10 пг/мл [22]. Вплив естрогенів на глюкозний гоместаз опосередований підвищенням синтезу глобулінів, що зв'язують статеві гормони (ГЗСГ) в печінці, що призводить до зниження біодоступності андрогенів. Використовуючи внутрішньовенний оральний тест толерантності до глюкози Walton і співав. спостерігали 30 \% зниження інсуліннезалежної утилізації глюкози у жінок в постменопаузі порівняно 3 жінками в пременопаузі, тоді як чутливість до інсуліну фрактично підвищувалася на $50 \%$. Таким чином, вплив менопаузи на глюкозний гомеостаз може бути пов'язаний як зі змінами метаболізму інсуліну, так і зі змінами його кліренсу в печінці. 
Великі рандомізовані контрольовані дослідження показали, що менопаузальна гормональна терапія (МГТ) знижуе частоту цукрового діабету (ЦД) 2 типу у жінок [23, 24]. Незважаючи на встановлений в експерименті позитивний вплив активації естрогенів і естрогенових рецепторів на гомеостаз глюкози і профілактику ЦД 2 типу, вплив менопаузи на гомеостаз глюкози у жінок досі нез'ясований $[25,26]$. Частково це можна пояснити особливостями моделей менопаузи, які використовують в експерименті, наприклад оваріоектомія, тоді як природня менопауза у жінок - більш складне явище, що включає прогресуюче зниження секреції яечників, відносне підвищення рівня андрогенів, хронологічне старіння тканин, зміни складу тіла і зниження фізичної активності [27]. Показано, що більш низькі рівні естрадіолу $\left(\mathrm{E}_{2}\right)$ в пременопаузі під час ранього менопаузального переходу асоційовані з підвищеним ризиком розвитку ЦД 2 типу на 47 \%, що погоджуеться з теорією старіння яечників [28]. Проспективне когортне дослідження EPICInterAct показало, що рання менопауза (тобто більш тривалий дефіцит $\mathrm{E}_{2}$ ) пов'язана $з$ підвищенням ризику ЦД 2 типу на $32 \%$ порівняно 3 менопаузою в віці 50-54 років [29].

In vivo доведено, що зниження активності $\mathrm{E}_{2}$ через рецептори $\left(\mathrm{pE}_{2 \sigma}\right)$ е основним механізмом розвитку IP в постменопаузі [30]. В скелетних м'язах зниження активності $\mathrm{pE}_{2 б}$ може змінювати ділення митохондрій, гальмуючи окислення митохондріальних жирних кислот i вживання кисню, що провокує розвиток окислювального стресу i IP. За зниженні активації $\mathrm{pE}_{2 \sigma}$ в печінці гіперінсулінемія, викликана м'язовою IP, сприяє відкладенню ТГ в печінці, не пригнічуеться експорт ТГ з печінки, що призводить до стеатозу печінки і прогресуванню IP. В свою чергу, зниження активності $\mathrm{p}_{2 \sigma}$ в макрофрагах [31] і жировій тканині [32] також сприяє розвитку запалення, IP і атеросклерозу. У жінок в постменопаузі зниження активності $\mathrm{E}_{2}$ через $\mathrm{pE}_{2 \sigma}$ i $\mathrm{pE}_{2 \mathrm{~s}}$ знижує секрецію $\mathrm{i}$ життездатність островцевих в-клітин. Зниження активності $\mathrm{E}_{2}$ в менопаузі за рахунок $\mathrm{pE}_{2 \sigma}$, представляється важливим для чутливості в-клітин до метаболічних ушкоджень, яка погіршуеться із старінням і менопаузою [33, 34]. Діабетогенний ефект дефіциту естрогенів у період менопаузи у жінок не так клінічно очевидний, як в експерименті. У жінок у постменопаузі $\mathrm{E}_{2}$ синтезується в молочній залозі, мозгу, м'язах, кістках і жировій тканині і діє в них як пара- або аутокриний фрактор [35]. Таким чином, у жінок в постменопаузі периферичні ефекти $\mathrm{E}_{2}$ залежать від його біосинтезу 3 циркулюючого джерела андрогенів наднирникових залоз. Цікаво, що у нелікованих жінок у постменопаузі більш високі рівні $\mathrm{E}_{2}$ в крові асоційовані з високим ризиком ЦД 2 типу незалежно від IMT [36]. Враховуючи, що циркулюючі рівні $\mathrm{E}_{2}$ не відображають його дію в клітинах-мішенях у жінок у постменопаузі, рівень $\mathrm{E}_{2}$ може розглядатися як сурогатний маркер схильності до ЦД 2 типу [37].

Ожиріння, що розвивається в період клімактерію у більше ніж половини жінок старшої вікової групи, є однією з основних причин метаболічних порушень. Естрогени знижують кількість рецепторів до андрогенів у вісцеральній жировій тканині, перешкоджають розподілу жирової ткани за вісцеральним типом, сприятливо діють на нейроендокринний контроль харчової поведінки. Збільшення маси тіла в клімактерії призводить до розвитку МMC, основними проявами якого є абдомінальне ожиріння, ПГГ і дисліпідемія. Одним з ланцюгів патогенезу ожиріння за МMC є зниження швидкості базального метаболізму на тлі дефіциту статевих стероїдів. Так, гальмування базального метаболізму у жінок у період постменопаузи сприяе прибавці маси тіла на 3-4 кг за рік. За даними Healthy Women's Study, в перші три роки після менопаузи маса тіла жінки в середньому збільшується на 2-3 кг, через 8 років - на 5,5 кг. Жінки в віці 50-60 років продовжують набирати близько 0,68 кг на рік [38].

Менопаузальний перехід пов'язаний 3 несприятливими змінами в складі тіла, відкладенням жиру в черевній порожнині, що супроводжується підвищенням IP/гі- 
перінсулінемії, зниженням рівня ГЗСГ, i, як наслідок, підвищенням рівня вільного тестостерону і появами гіперандрогенії. Гіпоестрогенемія, відносна гіперандрогенія, зниження швидкості обмінних процесів, посилена глюкокортикоїдна стимуляція, падіння рівня гормону росту i гіперсимпатикотонія, які розвиваються в постменопаузі, сприяють збільшенню маси тіла і перерозподілу жирової тканини за андроїдним типом, який асоційований 3 комплексом гормональних і метаболічних фракторів ризику [39-41]. Показано, що маса вісцеральної жирової тканини значно збільшується в період менопаузального переходу і до менопаузи паралельно зі зниженням рівня $\mathrm{E}_{2}$ в крові [42]. Гіпоестрогенемія призводить до зниження експресії ядерних рецепторів і білків, необхідних для ефективного використання енергії (PPAR - рецептори, що активують проліферацію пероксисом), фрерментів i фракторів транскрипції, що беруть участь в метаболізмі жирних кислот і ліполізі, що сприяе розвитку ожиріння i/або формуванню метаболічних порушень у жінок в постменопаузі [43, 44].

Не викликає сумніву тісний зв'язок фрункціонування серцево-судинної і статевої систем у жінок. В деяких джерелах менопаузу розглядають як фрактор ризику CC3 [45, 46]. Встановлено, що вісцеральне ожиріння пов'язано з підвищеним ризиком IXC [47]. Taк, J. K. Park і співавт. виявлено кореляційну залежність індексу розподілу жиру в організмі з періодом менопаузи і наявністю основних факторів ризику ССЗ (АГ, ПГГ, дисліпідемія) [48]. Механізми захисної дії естрогенів на серцево-судинну систему багатофракторні [49]. По-перше, естрогени проявляють вазодилятаційний ефект, стимулюючи синтез оксиду азоту (NO) ендотеліальними клітинами судин. По-друге, нещодавніми дослідженнями підтверджено позитивний вплив $\mathrm{E}_{2}$ безпосередньо на міоцити і судинну стінку, обумовлений активацією кальцієвого транспорту і пригніченням активності ангіотензинперетворюючого ферменту. Доведено позитивний вплив на МГТ на підвищений судинний опір у менопаузі. Так, призначення $\mathrm{E}_{2}$ жін- кам в клімактеричному періоді з верифікованою IXC призводило до зменшення кількості епізодів ішемії міокарду. По-треттє, естрогени знижують рівень атерогених фрракцій ліпопротеїнів низької (ЛПНЩ) і дуже низької щільності (ЛПДНЩ) і підвищують вміст антиатерогених ліпопротеїнів високої щільності (ЛПВЩ), гальмують активність печінкової тригліцеридліпази, що призводить до підвищення рівня ЛПВЩ внаслідок затримки їх кліренсу [50]. Крім того, натуральні естрогени діють як антиоксиданти на серцевий м'яз [8].

В структурі причин смертності жіночого населення України ССЗ займають перше місце. Ризик летальних випадків від кардіоваскулярної патології в 5 раз вище, ніж від раку молочної залози. Так, відносний ризик IXC у жінок в постменопаузі приблизно в 2,7 рази вище, ніж у їх однолітків із збереженою фрункцією яєчників, а поширеність АГ складає 8,2 і 52,4\%, відповідно. У молодих жінок із хірургічною менопаузою після оваріоектомії ризик CC3 зростає в 5 раз [8]. Підвищений ризик СС3 обумовлений перерозподілом жирової тканини, появою різноманітних метаболічних, гемодинамічних, прозапальних змін і прямого впливу дефіциту естрогенів на судинну стінку [51, 52]. Естрогени володіють антипроліферативною активністю на гладком'язові клітини судин, знижують рівень альдостерону і кортизолу [53, 54].

Для розвитку СС3 велике значення мають концентрації в крові фрібриногену [51] та інгібітора активатора плазміногена 1 (ІАП-1) [55], які зростають у жінок в постменопаузі [3]. В літературі представлено дані про зв'язок гіпоестрогенемії з високим рівнем тканинного активатора плазміногена та IAП-1 у жінок в пери- і постменопаузі [56]. ІАП-1, що продукуеться адипоцитами висцеральної жирової тканини, позитивно корелює з рівнем інсуліну і ТГ, виступаючи фактором ризику розвитку і прогресування СС3 у жінок в постменопаузі.

Третина життя жінки припадає на постменопаузальний період [57], а у жінок із раньою менопаузою ще більше часу. Середній вік жінок у развинутих країнах поступово збільшуеться i, як очікуеться, 
до 2025 року сягне 82 років. У цьому контексті цікавим є зв'язок між ранньою менопаузою і частотою ССЗ. Показано, що рання менопауза пов'язана з підвищеним ризиком смертності від СС3 і від інших причин, а ризик розвику IXC на 50 \% вище; в той же час зв'язок між віком менопаузи і інсультом не прослідковуеться [45]. Порівнянно з жінками з менопаузою в віці 50-51 років, жінки з передчасною, ранньою і відносно ранньою менопаузою мали найвищі ризики першої нефратальної серцево-сосудинної події в віці до 60 років (HR 18,8, 1,40 і 1,17, відповідно) [58].

Дисліпідемія - один 3 важливих несприятливих наслідків дефіциту естрогенів. Слід відмітити, що для жінок гіпертригліцеридемія $є$ більш несприятливим прогностичним фрактором, ніж для чоловіків. Останні роки великий інтерес викликає ліпопротеїн а, підвищення вміст якого у жінок супроводжується 5-кратним зростанням частоти гострих коронарних подій $[59,60]$.

Участь IP у механізмах прогресування атеросклерозу складна і багатомірна. Атерогенна дія інсуліну обумовлюе його здатність стимулювати синтез атерогенних фрракцій ліпідів і проліферацію гладком'язових клітин в стінці артерій. Інсулін приймає участь в регуляції низки механізмів трансмембранного транспорту, тому гіперінсулінемія призводить до підвищення концентрації $\mathrm{Na}^{+}$i $\mathrm{Ca}^{2+}$ в цитоплазмі гладком'язових клітин артеріол, що супроводжується підвищенням їх чутливості до пресорного впливу норадреналіну і ангіотензину. Інсулін підвищує реабсорбцію $\mathrm{Na}^{+}$в нирках, сприяючи затримці позаклитинної рідини. Встановлено, що за IP змешується вивільнення NO, внаслідок чого підвищуеться чутливість судинної стінки до дії сосудозвужуючих речовин, порушуються процеси ендотелій-залежної вазодилатації; вільні жирні кислоти пригнічують активність NO-синтетази [61]. Вище вказанні зміни створюють умови для домінування процесів тромбоутворення і гіперкоагуляції над процесами фібринолізу, що часто зустрічається у пацієнток із гіперпластичними процесами в ендометрії.
Однією з причин атеротромботичного ураження коронарних артерій є гіпергомоцистеїнемія. Гіпергомоцистеїнемія у жінок в постменопаузі асоційована 3 підвищеним ризиком CC3. Частота гіпергомоцистеїнемії у жінок в постменопаузі становить 50-75 \% [62]. Найбільш значне підвищення рівня гомоцистеїну в крові спостерігається протягом 5-15 років після менопаузи [63]. Гіпергомоцистеїнемія не тільки стимулює утворення вільних радикалів в ендотеліоцитах, підвищує в них концентрацію ЛПНЩ і ЛПДНЩ, але і призводить до зниження продукції ендотеліального релаксуючого фрактору, сульфатованих глюкозаміногліканів, зниження еластичності внутрішньосудинної устілки (знижується синтез простацикліну). Формуеться судинний компонент тромбоваскулярної хвороби, який повністю співпадає 3 зародженням атеросклеротичного процесу [64].

Гіперсимпатикотонія - один із ключових елементів патогенезу АГ. В обмеженній кількості досліджень показано, що у жінок у менопаузі присутні характерні для симпатикотонії зміни в варіабельності ритму серця і патологічні типи мікроциркуляції [65]. Частота серцевих скорочень, як найбільш простий критерій, що опосередковано відображає рівень симпатичної активності, показала свою значущість для прогноза раптової коронарної смерті у жінок в постменопаузі [66].

Зміни адипокінового статусу у жінок із MMC є фракторами ризику розвитку онкопатології [67]. Показано зв'язок ожиріння 3 раком молочної залози, який частіше зустрічається у жінок в постменопаузі. Висунуті три основні гіпотези:

1) порушення обміну статевих гормонів (естрогенова гіпотеза),

2) дисбаланс у системі «інсулін - інсуліноподібний ростовий фактор-1»,

3) патофізіологічна роль адипоцитів, під якою розуміють розвиток і підтримку субклінічного запалення при ожирінні.

На особливу увагу заслуговує естрогенова гіпотеза, яка може бути застосована до постменопаузального раку молочної залози, яєчників і ендометрію. В основу 
гіпотези покладено доведений зв'язок надлишку жирової тканини, насамперед підшкірної, з підвищенням швидкості утворення $\mathrm{E}_{2}$ із андрогенних попередників [68, 69]. In vivo продемонстровано мітогенні i мутагенні ефекти $\mathrm{E}_{2}$ на епітелій молочної залози, в основі яких лежить пряма або опосередована індукція вільнорадикального пошкодження дезоксірибонуклеїнової кислоти, генна нестабільність і мутації, як в нормальних клітинах, так і в клітинах пухлини [69]. Аналіз клінічних спостережень доводить, що ризик постменопаузального раку молочної залози вдвічи вище у жінок із більш високими концентраціями наднирникових андрогенів, тестостерону і естрогенів та з низьким рівнем ГЗСГ [70].

Гіпоестрогенія в постменопаузі призводить до порушення фрункцій гіпоталамічної і лімбічної систем, секреції гормонів аденогіпофіза, зниження опіоїдергічної активності (в-ендорфіни), змінам у серотонінергічній системі, супроводжується зниженням дофамінергічного і підвищенням норадренергічного тонусу центральної нервової системи [71, 72]. Ці зміни в нейроендокринній системі проявляються різноманітними психоемоційними порушеннями: тревогою, депресією, безсонням, нервозністю, погіршенням когнітивних фрункцій, зниженням концентрації уваги, мотивації і статевого потягу [46].

Таким чином, обмінно-ендокринні порушення, що виникають в період інволюції репродуктивної системи у жінок, сприяють формуванню MMC і погіршують його перебіг. Наявність МС у жінки на вступі в менопаузальний перехід сприяе перебігу пременопаузального періоду по патологічному сценарію.

Клімактерій - оптимальний період для оцінки загального стану здоров'я жінки і для розробки заходів, метою яких є підготовка жінки до фрізіологічних змін, що асоціюються з менопаузою. Командний підхід із обов'язковим залученням ендокрино- лога дає можливість оптимізувати процеси діагностики і лікування ММС, забезпечити кращий результат і дозволяє лікарю досягти експертного рівня в вирішенні цієї конкретної медичної проблеми. Проте існує і інша сторона такого підходу - втрачається цілісність сприйняття існуючих проблем зі здоров'ям пацієнтки i, як наслідок, пацієнтка курсує між різними лікувальними установами, лікарі яких дають рекомендації відносно своєї вузької спеціалізації. При цьому, зазвичай, лікар загальної практики-сімейної медицини не бере участі в цьому процесі - традиційно пацієнтки більше довіряють вузьким спеціалістам. Як наслідок, ніхто не систематизує отримані пацієнткою рекомендації від вузких спеціалістів, не визначає єдину тактику, не домагається дотримання послідовності в виконанні рекомендацій, відбувається часта зміна лікарів i, як наслідок, відсутній довгоочікуємий ефект від лікування.

Головний принцип курації жінок із МMC — це комплексний і персоніфікований підхід за участі команди спеціалістів різного профілю (лікар загальної практики-сімейної медицини, ендокринолог, дієтолог, кардіолог, гінеколог, психоневролог), залучення пацієнтки до визначення реальних досягаємих цілей компенсації проявів MMC і моніторинг фракторів ризику i/або супутніх захворювань. В економічно розвинутих країнах цю проблему вирішують шляхом створення команди спеціалістів для вирішення конкретного клінічного випадка. Перевагою такого підходу $є$ те, що при цьому використовуються практичні рекомендації з лікування ММС, засновані на принципах доказової медицини: навчання хворих, залучення необхідних консультантів, проведення сучасних лабораторних і інструментальних методів дослідження, діагностики і лікування із забезпеченням відповідними лікарськими препаратами і перманентний моніторинг. 


\section{ЛITEPATУРA \\ (REFERENCES)}

1. Marlatt KL, Redman LM, Beyl RA, et al. Am J Obstet Gynecol 2019; 222(4). http://doi.org/10.1016/j.ajog. 2019.09.051.

2. Ward E, Gold EB, Johnson WO, et al. J Clin Endocrinol Metab 2019; 104(5): 1404-1412. http://doi.org/10.1210/ jc.2018-00941.

3. Mancia G, Cesana G, Kuulasmaa K, et al. PLoS One 2014; 9(9). http://doi.org/10.1371/journal.pone.0107294.

4. Tatarchuk TF. Reproduktyuna endokrynologija 2019; 46: 19-37. https://doi.org/10.18370/2309-4117.2019.46.19-37.

5. Potter B, Schrager S, Dalby J, et al. Primary Care 2018; 45(4): 625-641. http://doi.org/10.1016/j.pop.2018.08.001.

6. Gracia CR, Sammel MD, Freeman EW, et al. Menopause 2005; 12(2): 128-135. http://doi.org/10.1097/00042192200512020-00005.

7. Nelson HD. Lancet 2008; 371: 760-770. https://doi.org/ 10.1016/S0140-6736(08)60346-3.

8. Gold EB, Crawford SL, Avis NE. Am J Epidemiol 2013; 178: 70-83. http://doi.org/10.1093/aje/kws421.

9. Luborsky JL, Meyer P, Sowers MF, et al. Hum Reprod 2003; 18: 199-206. http://doi.org/10.1093/humrep/deg005.

10. Avis NE, Crawford SL, Greendale G, et al. JAMA Intern Med 2015; 175(4): 531-539. http://doi.org/10.1001/ jamainternmed.2014.8063.

11. Tuomikoski P, Savolainen Peltonen H. Maturitas 2017; 97: 61-65. http://doi.org/10.1016/j.maturitas.2016.12.010.

12. Seong-Hee Ko, Hyun-Sook Kim. Nutrients 2020; 12(1): 202. http://doi.org/10.3390/nu12010202.

13. Numao S, Katayama Y, Nakata Y, et al. J Physiol Anthropol 2020; 39: 12. http://doi.org/10.1186/s40101020-00222-0.

14. Sun L, Peng Y, Sharrow AC, et al. Cell 2006; 125(2): 247-2460. http://doi.org/10.1016/j.cell.2006.01.051.

15. Guo Y, Zhao M, Bo T, et al. Cell Res 2019; 29(2): 151-166. http://doi.org/10.1038/s41422-018-0123-6.

16. Chen Zhang, Meng Zhao, Zhengyang Li, Yongfeng Song. Int $J$ Endocrinol 2020. http://doi.org/10.1155/2020/ 7024321 .

17. Solov'eva AO, Balkarov MI, Smetnik VP, et al. Klin medicina 2005; 83(5): 42-45.

18. Chernjajeva AO, Mikitjuk MR, Karachencev JuI, Kravchun NO. Probl endokrin patologii' 2019; 2: 73-80. https://doi.org/10.21856/j-PEP.2019.2.11.

19. Barskova VG, Nasonova VA, Jakunina IA, et al. Terapevt arh 2005; 5: 58-62.

20. Mumusoglu S, Yildiz BO. Curr Vasc Pharmacol 2019; 17(6): 595-603. http://doi.org/10.2174/157016111666618 0904094149 .

21. Leeners B, Geary N, Tobler PN, Asarian L. Hum Reprod Update 2017; 23: 300-321. http://doi.org/10.1093/ humupd/dmw045.
22. Cervellati C, Bergamini CM. Clin Chem Lab Med 2016; 54(5): 739-753. https://doi.org/10.1515/cclm-2015-0807.

23. Espeland MA, Hogan PE, Fineberg SE, et al. Diabetes Care 1998; 21(10): 1589-1595. http://doi.org/10.2337/diacare.21.10.1589.

24. Margolis KL, Bonds DE, Rodabough RJ, et al. Diabetologia 2004; 47(7): 1175-1187. http://doi.org/10.1007/ s00125-004-1448-x.

25. Mauvais-Jarvis F, Clegg DJ, Hevener AL. Endocr Rev 2013; 34(3): 309-338. http://doi.org/10.1210/er.2012-1055.

26. Tiano JP, Mauvais-Jarvis F. Nat Rev Endocrinol 2012; 8: 342-351. http://doi.org/10.1038/nrendo.2011.242.

27. Harlow SD, Gass M, Hall JE, et al. J Clin Endocrinol Metab 2012; 97(4): 1159-1168. http://doi.org/10.1097/ gme.0b013e31824d8f40.

28. Park SK, Harlow SD, Zheng H, et al. Diabet Med 2017; 34(4): 531-538. http://doi.org/10.1111/dme.13301.

29. Brand JS, van der Schouw YT, Onland-Moret NC, et al. Diabetes Care 2013; 36(4): 1012-1019. http://doi.org/ 10.2337/dc12-1020.

30. Bryzgalova G, Gao H, Ahren B, et al. Diabetologia 2006; 49(3): 588-597. http://doi.org/10.1007/s00125-005-0105-3.

31. Ribas V, Drew BG, Le JA, et al. Proc Natl Acad Sci USA 2011; 108(39): 16457-16460. http://doi.org/10.1073/ pnas. 1104533108 .

32. Davis KE, D Neinast M, Sun K, et al. Mol Metab 2013; 2(3): 227-242. http://doi.org/10.1016/j.molmet.2013.05.006.

33. Kilic G, Alvarez-Mercado AI, Zarrouki B, et al. PLoS One 2014; 9(2). http://doi.org/10.1371/journal.pone.0087941.

34. Liu S, Le May C, Wong WP, et al. Diabetes. 2009. Vol. 58(10). P. 2292-2302. http://doi.org/10.2337/db09-0257.

35. Labrie F. J Steroid Biochem Mol Biol 2015; 145: $133-$ 138. http://doi.org/10.1016/j.jsbmb.2014.06.001.

36. Muka T, Nano J, Jaspers L, et al. Diabetes 2016; 66(3): 577-586. http://doi.org/10.2337/db16-0473.

37. Mauvais-Jarvis F. Diabetes 2017; 66(3): 568-570. http:// doi.org/10.2337/dbi16-0063.

38. Ekta Kapoor, Maria L. Collazo-Clavell, Stephanie S. Faubion. Mayo Foundation for Medical Education and Research 2017; 10: 1552-1558. http://doi.org/10.1016/j. mayocp.2017.08.004.

39. Ametov AS, Kamynina LL. Jendokrinologija 2012; 1: 1-8.

40. Troshina EA, Pokusaeva VN, Andreeva EN. Ozhirenie u zhenshhin, Moskva, 2017: $272 \mathrm{p}$.

41. Douchi T, Yamamoto S, Yoshimitsu N, et al. Maturitas 2002; 42: 301-306. http://doi.org/10.1016/s0378-5122(02) 00161-5.

42. Lovejoy JC, Champagne CM, de Jonge L, et al. Int $J$ Obes (Lond) 2008; 32: 949-958. http://doi.org/10.1038/ ijo.2008.25. 
43. Al-Safi ZA, Polotsky AJ. Best Pract Res Clin Obstet Gynaecol 2015; 29(4): 548-553. http://doi.org/10.1016/j. bpobgyn.2014.12.002.

44. Kamei Y, Suzuki M, Miyazaki H, et al. J Nutr Sci Vitaminol (Tokyo) 2005; 51(2): 110-117. http://doi.org/10. 3177/jnsv.51.110.

45. Muka T, Oliver-Williams C, Kunutsor S. JAMA Cardiol 2016; 1: 767-776. http://doi.org/10.1001/jamacardio.2016. 2415 .

46. Wellons M, Ouyang P, Schreiner PJ, et al. Menopause 2012; 19: 1081-1087. http://doi.org/10.1097/gme.0b013e $3182517 \mathrm{bd} 0$.

47. Braga VA, Couto GK, Lazzarin MC, et al. PLoS One 2015; 10(4). http://doi.org/10.1371/journal.pone.0125388.

48. Park JK, Lim YH, Kim KS, et al. J Womens Health (Larchmt) 2013; 22(7): 587-594. http://doi.org/10.1089/ jwh.2012.4035.

49. Ratiani L, Parkosadze G, Cheishvili M, et al. Georgian medical news 2012; 203: 11-16.

50. Rekomendacii Amerikanskoj associacii serdca i insul'ta. Al'manah reproduktivnogo zdorov'ja, Kiev, 2014: 145-153.

51. Anichkov DA, Shostak NA, Zhuravleva AD. Racional'naja farmakoterapija $v$ kardiologii 2005; 1(1): 37-42.

52. Martínez JA, Palacios S, Chavida F, Pérez M. Rural Remote Health 2013; 13(2): 1865-1869.

53. Karvonen-Gutierrez C, Kim C. Healthcare (Basel) 2016; 4: 42-48. http://doi.org/10.3390/healthcare4030042.

54. North American Menopause Society. Menopause Practice: A Clinician's Guide. 5th ed. North American Menopause Society, Mayfield Heights, 2014; 92.

55. Smith FB, Lee AJ, Fowkes FJR, et al. Arteriosclerosis, Thrombosis, and Vascular Biology 1997; 17: 3321-3325. http://doi.org/10.1161/01.atv.17.11.3321.

56. Lee AJ, Lowe GOD, Smith WSC, et al. Brit J Haematol 1993; 83: 616-621. http://doi.org/10.1111/j.1365-2141. 1993.tb04699.x.

57. Gold EB. Obstet Gynecol Clin North Am 2011; 38: 425 440. http://doi.org/10.1016/j.ogc.2011.05.002.
58. Zhu D, Chung HF, Dobson AJ, et al. Lancet Public Health 2019; 4(11): e553-e564. http://doi.org/10.1016/ S2468-2667(19)30155-0.

59. Superko HR. Front Biosci 2001; 6: 355-365 http://doi. org/10.2741/superko.

60. Superko HR. Am J Cardiol 1998; 82: 34-46. http://doi. org/10.1016/s0002-9149(98)00771-1.

61. Sareen S, Gropper JLS, James L. In Advanced Nutritionand Human Metabolism, 4thed, Wadsworth, Belmont, 2005: 159-161.

62. Mirhosseini SJ, Forouzannia SK, Mirhosseini SA, et al. Nigerian J Med 2012; 53(4): 192-195. http://doi. org/10.4103/0300-1652.107551.

63. Christodoulakos G, Panoulis C, Rizos D, et al. $M a$ turitas 2001; 39(2): 161-167. http://doi.org/10.1016/ s0378-5122(01)00207-9.

64. Kiseljov AR, Nejfel'd IV, Balashov SV. Klinicist 2014; 1: 8-14.

65. Seidova G. B. Region krovoobr i mikrocirk 2005; 4: 46-52.

66. Pustotina ZM, Larjova NV, Zhigzhitova EB, et al. Problemy zhenskogo zdorov'ja 2012; 7: 28-34.

67. Gabriela Berg, Viviana Mesch, Nestor Siseles. Curr Obstet Gynecol 2012; 1: 63-70. http://doi.org/10.1007/ s13669-012-0011-x.

68. Bershtejn LM. Vnegonadnaja produkcija jestrogenov (rol' v fiziologii i patologii), Sankt-Peterburg, 1998: 172 p.

69. Saluhov VV, Kadin DV. Med sovet 2019; 4. http://doi. org/10.21518/2079-701X-2019-4-94-102.

70. Wysowski DK, Comstock GW, Helsing KJ, Lau HL. Am J Epidemiol 1987; 125: 791-799. http://doi.org/10.1093/ oxfordjournals.aje.a114596.

71. Barton M. Curr Opin Lipidol 2013; 24(3): 214-220. http://doi.org/10.1097/MOL.0b013e3283613a94.

72. Bjorntorp P. Centralization of body fat. In: Bjorntorp P, International text book of obesity, Chichester, 2001: 213224. http://doi.org/10.1046/j.1365-2796.2001.00881.x. 


\section{МЕНОПАУЗАЛЬНИЙ МЕТАБОЛІЧНИЙ СИНДРОМ: ПОГЛЯД ЕНДОКРИНОЛОГА}

Чернявська I. В., Микитюк М. Р.

ДУ «Інститут проблем ендокринної патологї̈ ім. В. Я. Данилевського НАМН України», м. Харків, Україна;

Харківська медична академія післядипломної освіти МОЗ Украйни, м. Харків, Украӥна myroslavamk@ukr.net

Мета огляду - узагальнити сучасні знання про менопаузальний метаболічний синдром (MМС) і обгрунтувати необхідність застосування комплексного персоніфікованого командного підходу для курації жінок із цією патологією. В огляді представлено багатофакторний вплив обмінно-ендокринних порушень, характерних для періоду інволюції репродуктивної системи у жінок, які сприяють розвитку МMC і погіршують його перебіг. Третина життя сучасної жінки припадає на пери- і постменопаузу. Недооцінка вікових особливостей функціонування репродуктивної системи може призводити як до гіпердіагностики і невиправданим лікувальним заходам, так і до несвоєчасного виявлення латентної гінекологічної патології. Клімактерій - оптимальний період для оцінки загального стану здоров'я жінки і розробки заходів, метою яких є підготовка жінки до фізіологічних змін, асоційованих з менопаузою. Командний підхід дає можливість оптимізувати процеси діагностики і лікування ММС, забезпечити кращий результат і дозволяе лікарю досягти експертного рівня в вирішенні конкретної проблеми. Головний принцип курації жінок із ММС - це комплексний і персоніфікований підхід за участі команди спеціалістів різного профілю (лікар загальної практики-сімейної медицини, ендокринолог, діетолог, кардіолог, гінеколог, психоневролог), визначення сумісно з пацієнткою реальних цілей, компенсації проявів синдрому і моніторинг фракторів ризику і/або супутніх захворювань.

Ключові слова: менопауза, метаболічний синдром.

\section{MENOPAUSAL METABOLIC SYNDROME: AN ENDOCRINOLOGIST'S VIEW}

\section{Chernyavskya I. V., Mykytyuk M. R.}

«V. Danilevsky Institute for endocrine pathology problems National Academy of Medical sciences of Ukraine», Kharkiv, Ukraine;

Kharkiv medical academy of postgraduate education, Kharkiv, Ukraine myroslavamk@ukr.net

The purpose of this review is to summarize the current understanding of the menopausal metabolic syndrome (MMS) and to substantiate the need to use a complex personalized team approach to supervise women with this pathology. The review presents the multifactorial effect of metabolic and endocrine disorders characteristic of the period of involution of the reproductive system in women, contributing to the formation of MMS and aggravating its course. A modern woman spends a third of her life in peri- and postmenopausal women. Underestimation of the age-related characteristics of the functioning of the reproductive system can lead to overdiagnosis and unjustified therapeutic interventions, as well as to untimely detection of latent gynecological pathology. Menopause is the optimal period for assessing the general health of a woman and developing measures aimed at preparing a woman for the physiological changes associated with menopause. The team approach makes it possible to optimize the processes of diagnosis and treatment of MMS, to ensure the best result and allows the doctor to reach an expert level in solving a specific problem. The main principle of the supervision of women with MMS is a comprehensive and personalized approach with the participation of a team of specialists of different profiles (general practitioner, family medicine, endocrinologist, nutritionist, cardiologist, gynecologist, neuropsychiatrist), defining, together with the patient, the real goals of compensating for the manifestations of the syndrome and monitoring the existing factors risk and/or concomitant diseases.

Key words: menopause, metabolic syndrome. 